\title{
Comparison of Statistical Classification of Financial Instruments and the Relevant Contents of Accounting Standards
}

\author{
Xia Ouyang, Yuan Xiao* and Jiaming Zhong \\ School of Economics \& Management Xiangnan University Chenzhou, Hunan, China \\ jmzhongcn@163.com \\ *The corresponding author
} Keywords: Financial instruments; Statistical classification; Accounting standards for business
enterprises

\begin{abstract}
From the two perspectives of "statistical classification of financial instruments" and "accounting standards", this article provides a brief description of definition and classification standards of financial instruments, carry out comparative and analysis of five items one of which is special drawing rights, clearly state the specific pertinence of both of them in application in the economy and put forward some thoughts for application of financial instruments.
\end{abstract}

\section{Introduction}

On April 2, 2011, the People's Bank of China published four occupation standards examined and approved by CFSTC statistical classification and coding of financial instruments, common statistical terms of financial instruments, part 1 of statistical evaluation of financial instruments: deposit and part 2 of statistical classification of financial instruments: credit ( collectively called standards), and classify the financial instruments according to the principle of integrating with the international practice. On January 2017, the Ministry of Finance implemented the new accounting standards for business enterprises, in which there are four accounting standards of financial instruments that are accounting standards for business enterprises No.22-recognition and measurement of financial instruments, accounting standards for business enterprises No.23-transfer of financial assets, accounting standards for business enterprises No.24-hedging and accounting standards for business enterprises No.37-presentation of financial instruments (collectively called accounting standards ). The new accounting standards borrowed the concepts and methods of international accounting standards and carried out the convergence of substantiality of accounting standards in our country. In order to further perfect the contents of financial instruments and standard the use of financial instruments, this article compare the statistical classification of financial instruments and put forward some enlightenment on the use of financial instruments from the two perspectives standards and accounting standards.

\section{Definition of Financial Instruments}

Statistical classification and coding of financial instruments point out that financial instrument is finance contracting assigned between institutional units which may form the financial assets of an institutional unit and form the financial liabilities or equity instrument of other institutional units. It includes financial assets, financial liabilities, equity instrument and contingent instrument. In accounting standards, financial instrument is a contract which can form the financial assets of a enterprise and form the financial liabilities or equity instrument of other units which includes financial assets, financial liabilities and equity instrument.

Financial instruments in standards and accounting standards include financial assets, financial liabilities and equity instrument. But there is no contingent instrument in accounting standards, and there is contingent instrument in standards, because the financial contracting may be formed in the definition in standards, in other words, it is possible that the financial contracting can not be formed, and in the case of that, the contingent instrument is formed. 


\section{Classification Standards of Financial Instruments}

The classification standards adopted in standards is the liquidity characteristics of financial instruments, the legal characteristics with the form of the relationship of creditor and debtor, contingent or non-contingent characteristics, risky characteristics and term characteristics. The classification standards adopted in accounting standards is the purpose of acquiring the financial assets or undertaking the financial liabilities, whether the maturity is fixed, whether the recoverable amount is fixed or can be determined, whether there is clear intention to hold to maturity and whether there is the ability to hold to maturity. Comparatively speaking, the classification standards adopted in standards are more macroscopic and abstract than the classification standards adopted in accounting standards. In the practice, the correct judgments for the liquidity of financial instruments (includes negotiability, transferability, marketability and convertibility) and risk of the financial instruments need the use experience of financial instruments of enterprises, and even need the guidance of specialized financial institutions. The classification standards adopted in accounting standards are more microcosmic and specific. It is easy to get a conclusion for individual enterprise on the questions such as how to judge whether the maturity is fixed, how to judge whether the recoverable amount is fixed and how to judge whether there is the ability to hold to maturity.

\section{Comparison of Financial Instruments}

Special Drawing Rights. The special drawing rights in standards is international reserve assets which is created by international monetary fund and is allocated to member states for supplying the existing official reserves, and it is a right that the member state with the special drawing rights can unconditionally acquire foreign exchange or other reserve assets form international monetary fund or other member states.

The special drawing rights in accounting standards is a kind of reserve assets and accounting unit created by international monetary fund which usually be used for payment between member states and international monetary fund, and between the member states, and which also be known as "paper gold". It is a kind of right to use capital of member states allocated by international monetary fund. The member state with the balance of payments deficit can gain foreign exchange from the other member states appointed by the international monetary fund to pay the balance of payments deficit or repay the loan to the IMF with the special drawing rights. In additional, the special drawing rights also can be a part of international reserve as gold and freely convertible currency. But because the special drawing rights is just a kind of accounting unit and is not real money which can not be directly used for payment of trade or non-trade, the member state must change it to other currency when used.

In summary, the special drawing rights in standards and accounting standards all embody a certain payment ability between the member states of international monetary fund. But the special drawing rights in standards has more advantages than the special drawing rights in accounting standards such as more big scope of embodying the payment ability and more convenient use that the special drawing rights can act as equivalent currency in international trade without the changing from it to other currency.

Non-Stock Certificate. Non-stock certificate in standards is a kind of negotiable instrument which is an evidence of the pay obligation of the concerned units. It contains four types bond, bill, NCDS and other non-stock certificate. Bond is a kind of security which institutional unit issue for financing and promise to pay according to the agreed terms. Bill in general refer to a kind of negotiable certificate signed and issued by the drawer who agrees itself to or ask others to pay a certain amount unconditionally, and the holder of bill have a certain right. NCDS is a kind of negotiable deposit certificate issued by other deposit companies which has fixed denomination and term. Other non-stock certificates are the non-certificates which are out of the above ranges.

There is no specific definition of non-stock certificate in accounting standards, but it is indicated that non-stock certificates should include some forms such as bill receivable, notes payable, credit and bond payable in the classification in accounting standards. The difference is that there is no 
specific definition and the extensive range of non-stock certificates as the definition in standards. The similarity of them is that non-stock certificates are closed and negotiable instruments of enterprises.

Stock and Other Stock Rights. The stock and other stock rights in standards is the financial agreement and contract which contains all the rights of assignment on corporate income and all the rights of residual claim, and which usually with stock, participating certificate or the similar files as its evidence. Stock and other stock rights includes the stock right of the asset side and the stock right of stakeholder. The stock right of the asset side generally refer to a kind of equity assets enterprise have or controlled which can be measured by currency, bring future economic interest for company and mainly participate in the profit distribution of other enterprises. The stock right of stakeholder generally refer to rights and interests the investor of enterprises have which is on behalf of its own net asset of enterprise.

The stock and other stock rights in accounting standards refer to the common stock issued by enterprises and stock options. Common stock refer to the stock with common rights on the operating management and the distribution of earnings and property. Common stock is on behalf of the right of claim for earnings and the residual estate of enterprise after meeting all the demands of creditor's rights payment and the income right and recourse of preferred shareholder which is the foundation of corporate capital, a basic form of stock and the most important stock with the largest issued amount. Stock options is refer to the right of choice delegated to company personnel that they can buy a certain number of stocks at a certain price in a certain future period.

From the extents expressed, the contents of stock and other stock rights in standards and accounting standards are similar, both are a kind of equity assets defined for the claim of company(or the asset side) for the earnings and the residual estates of enterprises. The expression of stock and other stock rights in standards is more macroscopic, and the expression of stock and other stock rights in accounting standards is more specific and fit the accountant work of enterprise.

Insurance Technical Reserve. Insurance technical reserve in standards is refer to various amounts deposited by the insurance company for carry out its obligations of compensation and paying insurance money within the term of an insurance policy which includes the net stock right of households for pension fund and reserve in respect of life insurance, advance payment of insurance and outstanding claim reserve. It includes reserves in respect of life insurance and reserve in respect of no-life insurance. Reserves in respect of life insurance is refer to the financial readiness deposited by the insurance company for the future insured liability of life insurance. Reserve in respect of no-life insurance is refer to the financial readiness needed by the insurance company in carrying out the outstanding responsibility of no-life insurance business.

There is no such a formulation called insurance technical reserve in the contents of financial instruments in accounting standards.

Other Accounts Receivable and Accounts Payable. Other accounts receivable and accounts payable in standards is refer to the activities of accounts receivable and accounts payable occurred in the internal of finance company and between its institutional units which mainly include accounts receivable and accounts payable, the provision for impairment of financial assets, business within the system and others. It includes business within the system, accounts receivable and accounts payable, the provision for impairment of financial assets and others. Business within the system is refer to the capital transactions in the internal of the juridical person of financial company. Accounts receivable and accounts payable is refer to accounts receivable and temporary payments and accounts receivable and temporary receipt in the business activities of finance company. The provision for impairment of financial assets is refer to assets impairment loss reserve brought by the provision of the potential asset loss after that the impairment test of financial assets is implemented by the finance company. Others is refer to other accounts receivable and accounts payable which are not in the above-mentioned range.

There is no definition of other accounts receivable and accounts payable in accounting standards. But it is indicated in the classification in accounting standards that there should be accounts receivable and accounts payable, and enterprises are explicitly required to measure at fair value in 
balance sheet and make its variation be included in the current profits and losses. If there are objective evidence which can clearly state that the financial assets impairment appeared, the impairment loss should be confirmed, and the impairment reserves should be accrued.

In summary, there are large differences between the brief content descriptions of financial instruments in standards and the brief content descriptions of financial instruments in accounting standards. The description of financial instruments in standards is mainly based on the financial instruments used between different financial institutions and between the financial institutions and non-financial institutions (insurance company is a example). The definition for the related items is mainly started from the macroscopic angle that is convenient for macroscopic monitoring and macroscopic readjustment and control. The description of financial instruments in accounting standards is mainly started from the microscopic angle, and more fit the accounting activity of the specific enterprise. The common consideration is the treatment of financial assets, financial liabilities and equity instrument used in the normal operations of the business of enterprises. The description of the specific items of financial instruments is more brief. The classification the items belong to is different even if there are overlaps for some items.

\section{Discussion}

Improvement of the Specialized Knowledge and Skills of Accountants of Enterprise. (1)We can know that there are large difference on the same object between standards and accounting standards from the comparison of the definition, classification standards and specific items in standards and accounting standards. These differences put forward higher request on the specialized knowledge of the accountants of enterprise. With the deepening of internationalization, the continuous convergence of accounting standards for business enterprise in our country with international financial reporting standards is being carried out that ask the accountants to update their own specialized 1 knowledge timely and learn the related maxims and standards published by the state.

(2) For financial instruments, standards published by the People's Bank of China which cover the on-balance sheet items and the off balance sheet activities, be applied to not only financial institutions in the banking sector but also some non-banking financial institutions such as insurance industry and securities industry and provide big guarantee for homogeneity, comparability and compatibility of mastering macro data. Although most enterprises are the manufacturing enterprises, with the expansion of trade at home and abroad, the general manufacturing enterprises has become closer with financial institutions in the banking sector and non-banking financial institutions that require the accountants of enterprise to study and be familiar with that how to carry out the determination, classification, measurement and disclosure of financial instruments for financial institutions in the banking sector and non-banking financial institutions in addition to master the accounting standards for business enterprise. However, the accountants of enterprises should continuously enrich their own knowledge and improve their professional ability for provide better services for enterprise.

(3) the differences of classification purpose, classification standards and statistic caliber on the statistical classification in standards and accounting standards make that the relevant statistical data of financial instruments has no comparability. The related accountants should make deeper understanding for these differences in order to improve the specialized knowledge and make the the related business management and work be carried out smoothly.

Information Disclosure of Enterprise. Although there are differences on the statistical classification and other aspects in standards and accounting standards, the information disclosure of enterprise should not only observe the request of accounting standards but also be compliance with the regulations of standards that invisibly increase the disclosure cost of accounting information of enterprise. If standards can be a reference for the development of accounting standards, and the classification of financial instruments in accounting standards is supposed to try to converge with the classification of financial instruments in standards, the disclosure cost of accounting information of enterprise will be reduced. At the same time, the consideration we need is 
that the data differences of financial instruments based on the statistical classification in standards or accounting standards because of the differences of statistical range and statistical caliber should be pointed out to make the external information users of enterprises be easy to use information and make correct decision when the information disclosure is implemented.

\section{Acknowledgement}

This study is supported by Scientific Research Fund of Hunan Provincial Education Department (Effect of Governance on Earnings Management of the Board of Directors of Finance(16C1510)), the Teaching Reform and Study Program for Higher Education of Hunan Province in 2016( namely ""Statistics" Teaching Reform and Practice in Management Major of Applied Universities on the Basis of Project Teaching")(XiangJiaoTong[2016]No.400-747).

\section{References}

[1] Information on http://www.casc.org.cn/.

[2] Editorial Committee of Accounting Standards for Business Enterprises: Explanation of Cases of Accounting Standards for Business Enterprises( Lixin Accounting Press, China 2016 ).

[3] Y.X. Zou: China Journal of Commerce. Vol.555 (2012) No.28, p.160-162.

[4] Diana Cozma Ighian: Economics and Applied Informatics, (2012).

[5] X.B. Ning: Communication of Finance and Accounting, Vol.572 (2012) No.24, p. 12-14.

[6] Y.W. Zhang: Commercial Accounting, Vol.499 (2012) No.19, p. 81-83. 